\title{
The Investigation of Communication Skills of Students at Different Departments at a State University in Turkey
}

\author{
Meryem ALTUN ${ }^{1}$, Necmettin KÜRTÜL ${ }^{2}$, Merve SOYCAN ${ }^{3}$ \\ ${ }^{1}$ Nigde Omer Halisdemir University, School of Physical Education and Sports, Turkey \\ ${ }^{2}$ Nigde Omer Halisdemir University, School of Foreign Languages, Turkey \\ ${ }^{3}$ Nigde Omer Halisdemir University, Teaching Fine Arts, Department of Teaching Music, Turkey
}

\begin{abstract}
:
The main purpose of this study was to investigate communication skills of students studying at different departments at a state university. The survey model was used in the study. The data were collected by the Effective Communication Skills Scale developed by Buluş et al., (2017). The sample of the study consists of 277 university students studying in different departments. According to the results of the research; it was found that there was a significant difference between gender variable and active participative listening and empathy subscale. Moreover, it was seen that this difference was in favor of women in both subscales. Considering the differences in terms of groups, it was found that the difference was determined among the departments of coaching, art, music and Teaching Physical Education and Sports, which was in favor of the department of coaching. In the literature, the communication skills could be higher in departments of art, music and Teaching Physical Education and Sports. The results obtained in the current study were contradictory to the above mentioned statement. It can be concluded that during the coaching practices, the coaches interact with sportsmen and other individuals as well as the courses they take during their education are the reasons why they have high communication skills than other departments.
\end{abstract}

Keywords: Communication Skills, University Students, Different Departments

\section{Introduction}

The concept of communication originates from the Latin root of "communis, communicare" and is considered as a process of trying to understand and interpret the messages participants send to each other by constructing knowledge or symbols (Dökmen, 2015).This concept has been defined by different scholars in different ways. According to Adair (2013) it is "a process in which a person relies on communication with another person, which is exchanged by the use of common symbols among people", Cüceloğlu (2000) defines it as "the process of expressing the exchange of thoughts and senses among individuals". It can be said that these definitions include the process of transferring and linking individuals to understanding and expressing themselves to others. This key focus is important in that it addresses the need for communicating with each other in order to have effective communication skills so that the interaction processes can be conducted in a proper manner (Buluş, et al., 2017). Skill is defined as "the ability of a person to accomplish a task depending on his / her predisposition and learning, and to conclude an action appropriately in accordance with his/her skill" (Turkish Language Society, 2016).

Communication skills are the basis for several aspects, and sensitivity to verbal and nonverbal messages can be summarized as effective listening and effective response (Bayram, 2013).An individual with good communication skills attempt to evaluate all the difference behavior and clues about the inner world of the person she/he communicates with (Cüceloğlu, 2013). In order for the effective communication process to take place, there is a need for a sender that communicates emotions and thoughts in general with symbols and a receiver, message, code, channel, feedback and understanding of such symbols (Dubrin, 2007).Some qualifications required in this context are as follows; during the process of interaction, speakers are asked to express their feelings and thoughts, to ask open questions, to solve meanings of body language messages, to react to messages, to be willing to listen, to establish eye contact, concentrate on the 
idea, give correct feedback, to show understanding, to look positive towards criticism, to be an entrepreneur, to use approaches to effective conflict resolution, and unconditional acceptance (Çamliyer and Çamliyer, 1997). Based on the current literature, according to theoretical explanations, five basic communication skills (Ego Supportive Language, Active-Participative Listening, Selfrecognition/Self-disclosure, Empathy and Ilanguage) were described within the conceptualized communication skills framework.

Supportive Language is a type of expression which has a positive effect on self in interpersonal relationships. During the communication process, it is aimed to realize the necessary changes by emphasizing the positive characteristics and performances of the individual through this skill. Without causing a weak and insufficient feeling in the person being communicated by prioritizing sufficiency, deficiencies are mentioned; thus, the person can eliminate those deficiencies (Whirter \& Voltan-Acar, 2005). The second skill, ActiveParticipative Listening, is active participation to the current moment with enough motivation and attention in order to contribute to understand the message of the person. The third skill, Selfrecognition/Self-disclosure, is to know about himself/herself, establishing sufficient relationship between thoughts and emotions and disclosure himself/herself willingly. The fourth skill, Empathy, is handled as an approach in literature and it is the most emphasized basic skill of them all. This skill is to understand the other person through his/her own subjective point of view; and thus, transmitting those understood emotions, thoughts and expectations to that person in return. The last skill in the framework, I-language, is to resend the effects of unwanted behaviors on the listener to the source of the message. I-language does not include statements of judgment, criticism, accusation etc. (Whirter \& Voltan-Acar, 2005).

\section{Method}

\subsection{The Design of the Study}

The survey model was used in the study. Survey models are a research approach aimed at describing in a way that is a situation existing in the past or present (Büyüköztürk, 2012).

\subsection{Participants}

The sample of the study consists of university 277 students studying in different departments (Teaching Physical Education, Music, Art and Coaching) at Niğde Ömer Halisdemir University.

\subsection{Data Collection Tool}

As data collection tool, Effective Communication Skills Scale developed by Buluş et al., (2017) was used. The results of the analyzes are as follows: KMO value is .89 and Barlett globality test result is $\chi^{2}=5955.697 ; \mathrm{p}<0.001$. When Cronbach's alpha coefficients were examined, the Empathy subscale had the highest coefficient with .85 and Ego Supporting Language subscale had the lowest coefficient with .73.In this study, all the questionnaires were applied by the researcher. Participants were all personally trained. 292 questionnaires were distributed during this process. 15 of the 292 questionnaires were deemed invalid and the remaining 277 questionnaires were evaluated.

\subsection{Data Analysis}

Statistical analyzes of the data were conducted through the SPSS 21.0 package program. Kolmogorov Smirnov and Shapiro Wilk tests of normality distribution tests were conducted to determine whether the data showed primarily normal distribution in the analysis phase. Afterwards, some descriptive statistics were conducted. It was determined that the data did not show normal distribution, in which the Mann Whitney U test was used for binary comparisons, and the Kruskal Wallis test was used for multiple comparisons. In addition, Spearman Correlation test was conducted to determine the relationship between the independent variables and the sub-scales. Research on communication skills in the country has been conducted in various working groups such as adult individuals, workplace employees, parents, institutional managers, adolescents, teachers and teaching staff. Given the nature of the education, the communication skills of the students studying at the faculty of education is of great importance. In this respect, it is aimed to investigate the communication skills of the students who study in different departments in Niğde Ömer Halisdemir University, in Turkey as well as determining to what extend their departments have effects on the level of communication skills.

\section{Findings}


Table 1. Frequency Distributions of Department, Grade and Gender Variables

\begin{tabular}{|l|l|l|l|l|}
\hline Variable & & $\mathbf{f}$ & $\%$ & Total \\
\hline \multirow{5}{*}{ Department } & Art & 42 & 15,2 & $100 \%$ \\
\cline { 2 - 4 } & Music & 70 & 25,3 & 277 \\
\cline { 2 - 4 } & Teaching & 84 & 30,3 & \\
& SPES & & & \\
\cline { 2 - 4 } & Coaching & 81 & 229,2 & \\
\hline \multirow{5}{*}{ Grade } & Grade 1 & 150 & 54,2 & $100 \%$ \\
& $\begin{array}{l}\text { Grade 2 } \\
\text { and 4 }\end{array}$ & 127 & 45,8 & 277 \\
\hline \multirow{2}{*}{ Gender } & $\begin{array}{l}\text { Female } \\
\text { Male }\end{array}$ & 138 & $\begin{array}{l}49,8 \\
50,2\end{array}$ & $\begin{array}{l}100 \% \\
277\end{array}$ \\
\hline
\end{tabular}

When table 1 is examined, it is found that the highest distribution in the departmental distribution was the teaching SPES $(n=84)$, the highest participation in the grade distribution was in Grade 1 $(n=150)$.

Table 2. Descriptive Statistics of Age Variables

\begin{tabular}{|l|l|l|l|l|l|}
\hline Variable & $\mathbf{n}$ & $\mathbf{X}$ & Ss & Youngest & $\begin{array}{l}\text { Oldes } \\
\mathbf{t}\end{array}$ \\
\hline Age & $\begin{array}{l}27 \\
7\end{array}$ & 20,3 & 2,14 & 18,00 & 31,00 \\
\hline
\end{tabular}

Table 2 shows the descriptive statistics for the age variable, and it is seen that the average age of participants is 20.3 , the youngest age is 18 , and the oldest age is 31 .

Table 3. Differences between Grade Variable and Sub-Scales (Mann Whitney U)

\begin{tabular}{|c|c|c|c|c|c|c|c|c|}
\hline Sub-Scales & $\begin{array}{l}\text { Grad } \\
\text { e }\end{array}$ & $\mathbf{N}$ & S.O. & S.T. & $U$ & $Z$ & $\mathbf{P}$ & Language \\
\hline $\begin{array}{l}\text { Ego Supportive } \\
\text { Language }\end{array}$ & $\begin{array}{l}\text { Grade } \\
1 \\
2 \text { and } \\
4\end{array}$ & $\begin{array}{l}150 \\
127\end{array}$ & $\begin{array}{l}145,7 \\
0 \\
131,0 \\
9\end{array}$ & $\begin{array}{l}21855,0 \\
0 \\
16648,0 \\
0\end{array}$ & $\begin{array}{l}8520,0 \\
0\end{array}$ & $\begin{array}{l}- \\
1,5 \\
2\end{array}$ & $\begin{array}{l}0,1 \\
3\end{array}$ & \\
\hline $\begin{array}{l}\text { Active } \\
\text { Participative } \\
\text { Listening }\end{array}$ & $\begin{array}{l}\text { Grade } \\
1 \\
2 \text { and } \\
4\end{array}$ & $\begin{array}{l}150 \\
127\end{array}$ & $\begin{array}{l}146,1 \\
1 \\
130,6 \\
1\end{array}$ & $\begin{array}{l}21916,0 \\
0 \\
16587,0 \\
0\end{array}$ & $\begin{array}{l}8459,0 \\
0\end{array}$ & $\begin{array}{l}- \\
1,6 \\
1\end{array}$ & $\begin{array}{l}0,1 \\
1\end{array}$ & $\begin{array}{l}\text { Active } \\
\text { Participative } \\
\text { Listening }\end{array}$ \\
\hline $\begin{array}{l}\text { Self- } \\
\text { recognition/Self- } \\
\text { disclosure }\end{array}$ & $\begin{array}{l}\text { Grade } \\
1 \\
2 \text { and } \\
4 \\
\end{array}$ & $\begin{array}{l}150 \\
127\end{array}$ & $\begin{array}{l}133,5 \\
0 \\
145,5 \\
0 \\
\end{array}$ & $\begin{array}{l}20024,5 \\
0 \\
18478,5 \\
0 \\
\end{array}$ & $\begin{array}{l}8699,5 \\
0\end{array}$ & $\begin{array}{l}- \\
1,2 \\
5\end{array}$ & $\begin{array}{l}0,2 \\
1\end{array}$ & \\
\hline Empathy & $\begin{array}{l}\text { Grade } \\
1 \\
2 \text { and } \\
4 \\
\end{array}$ & $\begin{array}{l}150 \\
127\end{array}$ & $\begin{array}{l}137,4 \\
8 \\
140,7 \\
9 \\
\end{array}$ & $\begin{array}{l}20622,5 \\
0 \\
17880,5 \\
0\end{array}$ & $\begin{array}{l}9297,5 \\
0\end{array}$ & $\begin{array}{l}- \\
0,3 \\
4\end{array}$ & $\begin{array}{l}0,7 \\
3\end{array}$ & $\begin{array}{l}\text { Self- } \\
\text { recognition/Sel } \\
\text {-disclosure }\end{array}$ \\
\hline $\begin{array}{l}\text { Use of I- } \\
\text { language }\end{array}$ & $\begin{array}{l}\text { Grade } \\
1 \\
2 \text { and } \\
4 \\
\end{array}$ & $\begin{array}{l}150 \\
127\end{array}$ & $\begin{array}{l}138,0 \\
2 \\
140,1 \\
5 \\
\end{array}$ & $\begin{array}{l}20703,5 \\
0 \\
17799,5 \\
0\end{array}$ & $\begin{array}{l}9378,5 \\
0\end{array}$ & $\begin{array}{l}- \\
0,2 \\
2\end{array}$ & $\begin{array}{l}0,8 \\
3\end{array}$ & \\
\hline
\end{tabular}

When table 3 is examined, it is found that there is no significant difference between the class variable and sub-scale $(\mathrm{p}<0.05)$.
Table 4. Differences between Gender Variables and Sub-Scales (Mann Whitney U)

\begin{tabular}{|c|c|c|c|c|c|c|c|}
\hline Sub-Scales & $\begin{array}{l}\text { Gende } \\
r\end{array}$ & $\mathbf{N}$ & S.O. & S.T. & $\mathbf{U}$ & $\mathbf{Z}$ & $\mathbf{P}$ \\
\hline $\begin{array}{l}\text { Ego Supportive } \\
\text { Language }\end{array}$ & $\begin{array}{l}\text { Female } \\
\text { Male }\end{array}$ & $\begin{array}{l}138 \\
139\end{array}$ & $\begin{array}{l}141,9 \\
4 \\
136,0 \\
8 \\
\end{array}$ & $\begin{array}{l}19587,5 \\
0 \\
18915,5 \\
0 \\
\end{array}$ & $\begin{array}{l}9185,5 \\
0\end{array}$ & $\begin{array}{l}- \\
0,6 \\
1\end{array}$ & 0,54 \\
\hline $\begin{array}{l}\text { Active } \\
\text { Participative } \\
\text { Listening }\end{array}$ & $\begin{array}{l}\text { Female } \\
\text { Male }\end{array}$ & $\begin{array}{l}138 \\
139\end{array}$ & $\begin{array}{l}152,2 \\
8 \\
125,8 \\
2 \\
\end{array}$ & $\begin{array}{l}21014,5 \\
0 \\
17488,5 \\
0 \\
\end{array}$ & $\begin{array}{l}7758,5 \\
0\end{array}$ & $\begin{array}{l}- \\
2,7 \\
6\end{array}$ & 0,01 \\
\hline $\begin{array}{l}\text { Self- } \\
\text { recognition/Self- } \\
\text { disclosure }\end{array}$ & $\begin{array}{l}\text { Female } \\
\text { Male }\end{array}$ & $\begin{array}{l}138 \\
139\end{array}$ & $\begin{array}{l}141,3 \\
3 \\
136,6 \\
9 \\
\end{array}$ & $\begin{array}{l}19503,5 \\
0 \\
18999,5 \\
0 \\
\end{array}$ & $\begin{array}{l}9269,5 \\
0\end{array}$ & $\begin{array}{l}- \\
0,4 \\
9\end{array}$ & 0,63 \\
\hline Empathy & $\begin{array}{l}\text { Female } \\
\text { Male }\end{array}$ & $\begin{array}{l}138 \\
139\end{array}$ & $\begin{array}{l}148,7 \\
6 \\
129,3 \\
1 \\
\end{array}$ & $\begin{array}{l}20529,5 \\
0 \\
17973,5 \\
0 \\
\end{array}$ & $\begin{array}{l}8243,5 \\
0\end{array}$ & $\begin{array}{l} \\
2,0 \\
3\end{array}$ & 0,04 \\
\hline $\begin{array}{l}\text { Use of I- } \\
\text { language }\end{array}$ & $\begin{array}{l}\text { Female } \\
\text { Male }\end{array}$ & $\begin{array}{l}138 \\
139\end{array}$ & $\begin{array}{l}144,8 \\
9 \\
133,1 \\
5\end{array}$ & $\begin{array}{l}19994,5 \\
0 \\
18508,5 \\
0\end{array}$ & $\begin{array}{l}8778,5 \\
0\end{array}$ & $\begin{array}{l} \\
1,2 \\
3\end{array}$ & 0,22 \\
\hline
\end{tabular}

In table 4, when differences between gender variables and sub-scales are examined, it is found that there is a significant difference between gender variables and 'Active Participative Listening' subscale $(\mathrm{p}=0,01)$ and empathy subscale $(\mathrm{p}=0,04)(\mathrm{p}$ $<0,05)$. It is also seen that this difference is in favor of both sub-scales (active participative listening female $=152.28 /$ male $=125.82$, empathy - female $=$ $148.76 /$ male $=129.31$ ) .

Table 5. The Differences between Department Variable and Sub-Scales (Kruskal Wallis)

\begin{tabular}{|c|c|c|c|c|c|c|c|}
\hline Sub-Scales & Groups & $\mathbf{N}$ & S.O. & Sd & $x^{2}$ & $p$ & $\begin{array}{l}\text { Differenc } \\
\text { e Group }\end{array}$ \\
\hline $\begin{array}{l}\text { Ego Supportive } \\
\text { Language }\end{array}$ & $\begin{array}{l}\text { Art } \\
\text { Music } \\
\text { Teaching } \\
\text { SPES } \\
\text { Coaching }\end{array}$ & $\begin{array}{l}41 \\
70 \\
84 \\
81\end{array}$ & $\begin{array}{l}123,6 \\
4 \\
135,6 \\
2 \\
145,5 \\
3 \\
143,1 \\
1\end{array}$ & 3 & 2,46 & 0,48 & \\
\hline $\begin{array}{l}\text { Active } \\
\text { Participative } \\
\text { Listening }\end{array}$ & $\begin{array}{l}\text { Art } \\
\text { Music } \\
\text { Teaching } \\
\text { SPES } \\
\text { Coaching }\end{array}$ & $\begin{array}{l}41 \\
70 \\
84 \\
81\end{array}$ & $\begin{array}{l}132,8 \\
3 \\
142,6 \\
4 \\
141,6 \\
3 \\
136,3 \\
3\end{array}$ & 3 & 0,58 & 0,90 & \\
\hline $\begin{array}{l}\text { Self- } \\
\text { recognition/Self } \\
\text {-disclosure }\end{array}$ & $\begin{array}{l}\text { Art } \\
\text { Music } \\
\text { Teaching } \\
\text { SPES } \\
\text { Coaching }\end{array}$ & $\begin{array}{l}41 \\
70 \\
84 \\
81\end{array}$ & $\begin{array}{l}130,4 \\
8 \\
132,4 \\
1 \\
134,7 \\
0 \\
153,5 \\
7\end{array}$ & 3 & 3,92 & 0,27 & \\
\hline Empathy & $\begin{array}{l}\text { Art } \\
\text { Music } \\
\text { Teaching } \\
\text { SPES } \\
\text { Coaching }\end{array}$ & $\begin{array}{l}41 \\
70 \\
84 \\
81\end{array}$ & $\begin{array}{l}108,5 \\
0 \\
142,4 \\
1 \\
146,3 \\
0 \\
144,3 \\
0\end{array}$ & 3 & 7,31 & 0,06 & \\
\hline Use of I- & Art & 41 & 117,6 & 3 & 17,5 & 0,00 & $4-1$ \\
\hline
\end{tabular}




\begin{tabular}{|l|l|l|l|l|l|l|l|}
\hline language & Music & 70 & 0 & & 3 & & $4-2$ \\
& Teaching & 84 & 135,3 & & & & $4-3$ \\
& SPES & 81 & 0 & & & & \\
& Coaching & & 124,0 & & & & \\
& & & 168,6 & & & & \\
& & & 5 & & & & \\
\hline & & & & & & & \\
\hline
\end{tabular}

When table 5 is examined, it is found that there is a significant difference between the department variables and the language use sub-scale $(p=0.00)$. When the differences between these groups are examined, it is determined that there are significant differences between coaching department, art, music and teaching SPES, and in all three groups the differences are in favor of the coaching department.

Table 6.The Relationship between Age Variable and Sub-Scales

\begin{tabular}{|l|l|l|l|}
\hline & \multicolumn{2}{|l|}{ Age } \\
\hline & $\mathbf{n}$ & $\mathbf{r}$ & $\mathbf{p}$ \\
\hline $\begin{array}{l}\text { Ego Supportive } \\
\text { Language }\end{array}$ & 277 & $-0,03$ & 0,66 \\
\hline $\begin{array}{l}\text { Active Participative } \\
\text { Listening }\end{array}$ & 277 & 0,01 & 0,91 \\
\hline $\begin{array}{l}\text { Self- } \\
\text { recognition/Self- } \\
\text { disclosure }\end{array}$ & 277 & $-0,02$ & 0,80 \\
\hline Empathy & 277 & $-0,05$ & 0,44 \\
\hline Use of I-language & 277 & $-0,01$ & 0,93 \\
\hline & & & \\
\hline
\end{tabular}

In table 6 , the relationship between age variables and sub-scales are examined and it is clear that there is no significant relationship between age variable and sub-scales $(\mathrm{p}<0,05)$.

\section{Results and Discussion}

The main purpose of this study was to investigate communication skills of students studying at different departments at Niğde Ömer Halisdemir University in Turkey.

According to the findings obtained, when the difference between gender variables and effective communication skills sub-scales is examined; it is found that there is a significant difference between gender variable and active participative listening and empathy sub-scale.

It is also seen that this difference is in favor of females in both sub-scales. This result is supported by some research findings. The research conducted by Eagle (2013) revealed that there was a significant difference between the genders; besides, the level of communication skills of female students was higher than male students. In this case, that male and females have different characteristics may be the main reason for the difference. Even though male and females have similar living conditions in contemporary modern life, their gender characteristics may be the reason for such a difference.

However, some studies advocate contrary views. For example, according to the study conducted by Yilmaz (2007), it was showed that the communication skills did not differ according to gender, which is not in parallel with the current study.

According to the findings obtained, there is also a significant difference between the department variable and the I-language use sub-scale. When the differences between these groups were examined, it was determined that the differences were between coaching, art, music and teaching SPES departments, which was in favor of the coaching department. In a research conducted by Akyurt (2009), it was stated that there was a significant difference between the communication skills of the students and the departments in which they studied. Similarly, Toy (2007) found that students studying at the faculty law had higher communication skills than those studying at the faculty of engineering.

According to the results of the study conducted by Bayram et al. (2018), it was determined that significant differences were in the "value", "burden" and "motivation" sub-scales and the level of education differed from those of the universities with different levels of "respect", "expressive skill" and "democratic attitude" in terms of communication skills, which is due to the level of education provided by faculties. When these results are examined, it can be expected that the communication skills will be higher in art, music and teaching SPES departments when their courses they take during their education are considered. Yet, the results obtained in this study are contrary to above mentioned studies. This result may stem from the characteristics of the field itself since the coaching occupation has more interaction with sportsmen and other individuals.

The relationship between age and grade variables and sub-scales was examined, it was seen that there was no significant differences, which may stem from the fact that there is not big gap between ages. This view is supported by the studies in the current literature. In a study by Dölek (2015), it was stated that communication skills did not show any significant differences between the grades, which is supported by such studies as conducted by Dökmen 
(2015), Tepeköylü et al. (2009), Bingöl and Demir (2011).

When these results are taken into consideration, it may be stated that there are not enough courses related to communication skills in these departments since communication skills do not show any significant difference between the grades. In addition, the communication skills provided in existing courses may not develop students' communication skills.

In a study conducted by Nembaware (2018), the researcher prepared a program related to communication skills at a state university in Zimbabwe and the results of the study showed significant effects on students. Therefore, it can be determined that there is no significant difference between the communication skills according to the grade levels of university students. Therefore, courses related to the communication skills can be added to the current program or curriculum to improve students' communication skills at universities.

\section{Conclusion}

As a conclusion, the communication skills provided at the departments where the courses are predominantly related to educational sciences are lower than the other departments. In this respect, since the graduates will need communication skills in their professional lives, it is possible to emphasize courses related to communication skills in teaching departments, which can be improved in the same way.

\section{References}

[1] Adair, J. (2013). Etkili iletişim.(Ö. Çolakoğlu, Çev. ) İstanbul: Babıâli Kültür Yayıncılığı.

[2] Akyurt, N. (2009). Sağlıkta iletişim ve Marmara Üniversitesi Sağlık Hizmetleri Meslek Yüksekokulu öğrencilerinin iletişim becerileri.Fırat Sağlık Hizmetleri Dergisi, 4(11); 15-33.

[3] Bayram, L. (2013). Düzenli spor yapmanın 1slahevlerindeki çocuk ve gençlerin sosyal uyum ve iletişim becerileri üzerindeki etkisi.Yayımlanmamış Doktora Tezi. Ondokuz Mayıs Üniversitesi Sağlık Bilimleri Enstitüsü, Samsun.

[4] Bayram, A., Göker, S. D., Sarıkaya, H. S., Kumandaş Öztürk, H. (2018). Lisans, yüksek lisans ve doktora eğitimi verilen eğitim fakültelerindeki öğretim elemanlarının sınıf içi iletişim becerilerinin incelenmesi.Abant İzzet
Baysal Üniversitesi Eğitim Fakültesi Dergisi, 18 (1), 77-94.

[5] Buluş, M., Atan, A., Sarıkaya, H. E. (2017). Etkili iletişim becerileri: Bir kavramsal çerçeve önerisi ve ölçek geliştirme çalışması. International Online Journal of Educational Sciences, 9(2); 575 - 590 .

[6] Büyüköztürk, Ş. (2012). Sosyal bilimler için veri analizi el kitabı. Ankara: Pegem A Yayıncilik.

[7] Bingöl, G., Demir, A. (2011). Amasya sağlık yüksekokulu öğrencilerinin iletişim becerileri. Göztepe Tip Dergisi, 26; 152-159.

[8] Cüceloğlu, D. (2000). İnsan insana. İstanbul: Remzi Kitabevi.

[9] Cüceloğlu D. (2013).Yeniden insan insana.İstanbul: Remzi Kitabevi.

[10] Cüceloğlu, D. (2015). İletişim donanımları. İstanbul: Remzi Kitabevi.

[11] Çamlıyer H., Çamlıyer, H. (1997). Eğitim bütünlüğü içinde çocuk hareket eğitimi ve oyun. İzmir: Can Ofset.

[12]Dökmen, Ü. (2015). Sanatta ve günlük yaşamda iletişim çatışmaları ve empati.İstanbul: Remzi Kitapevi.

[13]Dölek, A., K. (2015). Üniversite öğrencilerinin iletişim becerilerinin farklı değişkenler açısından incelenmesi.Yüksek Lisans Tezi. Atatürk Üniversitesi Eğitim Bilimler Enstitüsü, Erzurum.

[14]Dubrin, A. J. (2007). Fundamentals of organizational behavior.Australia: Thomson South- Western.

[15] Kartal, M.A. (2013).Ortaöğretim öğrencilerinin bazı değişkenlere göre öznel iyi oluş ve

iletişim beceri düzeyleri.Yüksek Lisans Tezi. Ondokuz Mayıs Üniversitesi Eğitim Bilimler

Enstitüsü, Samsun.

[16] Nembaware, S. (2018). Perceptions of Chinhoyi University of Technology's staff and students regarding the Communication Skills course (Shadreck Nembaware, Chinhoyi University of Technology). International Journal of Scientific Research and Management (IJSRM), 6(3); 117-134.

[17] Önder, A. (2003). Ailede iletişim: konuşarak ve dinleyerek anlaşalım. İstanbul: Morpa Kültür ve Yayınları.

[18] TDK.(2016). Türk Dil Kurumu. www.tdk.gov.tr (Erişim tarihi: 27.06.2018)

[19] Tepeköylü, Ö., Soytürk, M., Çamlıyer, H. (2009). Beden Eğitimi ve Spor Yüksekokulu (BESYO) öğrencilerinin iletişim becerisi algılarının bazı değişkenler açısından 
incelenmesi.Spormetre Beden Eğitimi ve Spor Bilimleri Dergisi, 7; 115-124.

[20] Toy, S. (2007). Mühendislik ve hukuk fakülteleri öğrencilerinin iletişim becerileri açısından karşılaştırılması ve iletişim becerileriyle bazı değişkenler arasındaki ilişkiler.Yüksek Lisans Tezi. Ankara Üniversitesi, Ankara.

[21] Whirter, Mc. J., Voltan-Acar, N. (2005). Çocukla iletişim.İstanbul: Milli Eğitim Bakanlığı Yayınları.

[22] Yılmaz, B. (2007). Üniversite öğrencilerinin kişilerarası iletişim becerileri ve bağlanma stilleri arasındaki ilişki.Yayımlanmamış Yüksek Lisans Tezi Muğla Üniversitesi, Sosyal Bilimler Enstitüsü, Muğla.

[23] [Accessed: Sept. 12, 2004]. (General Internet site)

\section{Author Profile}

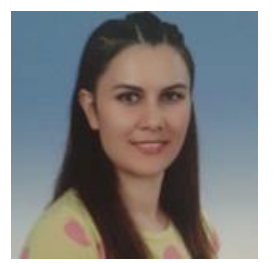

Meryem ALTUN ${ }^{1}$ received her BA, MA and $\mathrm{PhD}$ degrees in Physical Education and Sports from the Institute of Educational Sciences at Gazi University in Ankara 2009, 2014 and 2017 respectively. She works as a Lecturer Dr. at the School of Physical Education and Sports at Nigde Omer halisdemir University in Nigde.

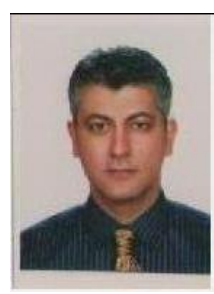

Necmettin KÜRTÜL ${ }^{2}$ received BA and MA degrees in English Language Department from Institute of Social Sciences in 1998 and 2015, respectively. In addition, he has continued his doctoral study at the same institute in Cukurova University in Adana since 2016 as well as working as a lecturer at the School of English at Omer Halisdemir University in Nigde.

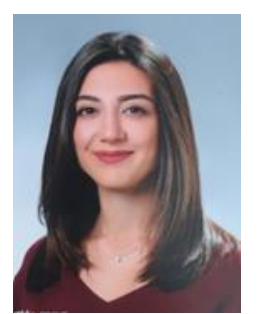

Merve SOYCAN $^{3}$ received BA degree in the Department of Teaching Music at the Faculty of Fine Arts at Selcuk University in Konya in 2011 and MA degree from Institute of Educational Sciences at Necmettin Erbakan University in Konya in 2013 and she has continued her doctoral studies since 2013. She has worked as a research assistant at the department of Fine Arts at Omer Halisdemir University in Nigde since 2017. 